\title{
Learn From Home and Alienation
}

\author{
Agustin Sukses Dakhi \\ Program Pancasila and Citizenship Education Study \\ High school Teacher training and Science Education in South Nias \\ Email: suksesdakhi@gmail.com
}

\begin{abstract}
.
Since the outbreak of corona virus spread in the ground water, has an effect on the world of education. The government took the policy to learn from home then the process of learning takes place online or online with the use of various applications such as Zoom, WhatsApp, Google Classroom, Google Meet, Cisco Webex, including learning through TVRI. Thus already four months the students not to school, not with friends, not meet with the teacher, no learning process in the class room, not in the school environment. This study aims to describe the state of alienation or alienated experienced by students since the learning at home. Data collection techniques with interviews to Junior high school students around the town of teluk-dalam road. The results showed that the Junior high students around the town of teluk-dalam road experiencing the symptoms of alienation.
\end{abstract}

Keywords: Learning from home, Alienation

\section{INTRODUCTION}

According to data from UNESCO, 12 March 2020, 29 countries have already close the school in order to prevention of an outbreak of corona virus. On March 18, increased to 112 Countries close the school. On March 23 in the Uk have started students study from home. So rapid development of this virus then eventually almost the entire world apply the learning from home for students and students. On 12 March 2020 the Ministry of Education and culture (Moec) issued a letter related to the prevention and handling of Covid-19. As well as the circular letter of the first number 2 of the year 2020 on the prevention and handling of Covid-19, and the second is the circular letter no. 3 year 2020 on the prevention of Covid-19 in the Educational Unit that contains a step to step guide prevent the growing spread of Covid-19 in the education unit. On March 16, the Governor of DKI Jakarta, AniesBaswedan announced distance learning (PJJ) in Jakarta. See the condition of the spread of the outbreak of corona virus is then some region in Indonesia off the students. Based on Circular Letter of March 17, 2020 then eventually the entire territory of Indonesia to carry out study from home or study online. A number of schools in Indonesia, including in the City of teluk-dalam road South Nias accustom to using technology devices in the learning process, although encounter problems mainly the network/signal or the student does not have an android and a laptop to access. Teachers send the material and tasks through WhatsApp, there are also learning to use apps Zoom, Google Meet, Google Classroom, Cisco Webex and other media. On 6 May the Minister of Education and Culture NadiemMakarim admitted online learning difficult but it is better there are online learning than there is absolutely no learning and it forced us to do given the health crisis.

According to data from UNESCO, 12 March 2020, 29 countries have already close the school in order to prevention of an outbreak of corona virus. On March 18, increased to 112 Countries close the school. On March 23 in the Uk have started students study from home. So rapid development of this virus then eventually almost the entire world apply the learning from home for students and students. On 12 March 2020 the Ministry of Education and culture (Moec) issued a letter related to the prevention and handling of Covid-19. As well as the circular letter of the first number 2 of the year 2020 on the prevention and handling of Covid-19, and the second is the circular letter no. 3 year 2020 on the prevention of Covid-19 in the Educational Unit that contains a step to step guide prevent the growing spread of Covid-19 in the education unit. On March 16, the Governor of DKI Jakarta, AniesBaswedan announced distance learning (PJJ) in Jakarta. See the condition of the spread of the outbreak of corona virus is then some region in Indonesia off the students. Based on Circular Letter of March 17, 2020 then eventually the entire territory of Indonesia to carry out study from home or study online. A number of schools in Indonesia, including in the City of teluk-dalam road South Nias accustom to using technology devices in the learning process, although encounter problems mainly the network/signal or the student does not have an android and a laptop to access. Teachers send the material and tasks through WhatsApp, there are also learning to use apps Zoom, Google Meet, Google Classroom, Cisco Webex and other media. On 6 May the Minister of Education and Culture NadiemMakarim admitted online learning 
difficult but it is better there are online learning than there is absolutely no learning and it forced us to do given the health crisis.

The application of learning from this house has changed the state of the learning process experienced by students. Students will no longer to school then the student may be too late to wake up in the morning, there is a reason students use the mobile phone his parents with the free reasons online learning, no longer heard the sound of saying goodbye to the school from students to parents, student did not meet again with a school friend so that the laughter, jokes, boisterous become lost, the student does not meet with the teacher, the school environment, which is usually used students to talk/chat with your friends it is no longer implemented, the atmosphere in the classroom that are also missed by the student instantly vanished. The activities of the students in the field of art, sports and others also lost in the swallow the earth. Seeing this situation, the writer is interested to conduct research in connection with the study of the home which experienced Middle and high School students around the town of teluk-dalam road in South Nias. The circumstances that change the total is very possible students experiencing symptoms of alienation or alienated against a friend, against a teacher, against the school environment, to the learning process and to yourself.

\section{METHOD RESEARCH}

This research type is qualitative descriptive with the technique of sampling is the sample proportion (Porpotional Sample). Data collection is done by observation and interview. Data analysis is data reduction, data presentation, data verification, test credibility, triangulation of sources, triangulation techniques and triangulation of time.

\section{RESULTS AND DISCUSSION}

Before applied learning from home students undergo his habit of day-to-day where waking up in the morning, saying goodbye to parents going to school, nothing in between, no walking, no riding in a rickshaw. In school they feel happy to meet friends always decorate with jokes and laughter, full of joy. They enjoy the togetherness in the cafeteria, in the library, in the cottage, under a tree, in the schoolyard, in classrooms and in all corners of the school building. Students meet with the teacher often guiding, advising or paying attention, especially students who have teachersfavourit and very in love. The learning process is also going well and the students can interact with the teacher through questions and answers and also with your friends through discussion in the classroom. Students really enjoy their daily activities in learning, including ektrakurikuler the field of art, sports and many other fields. Students feel pleased, happy and proud as part of his school by wearing uniforms, have friends, teachers and all the facilities in the school.

CHART: the State of student learning in the school

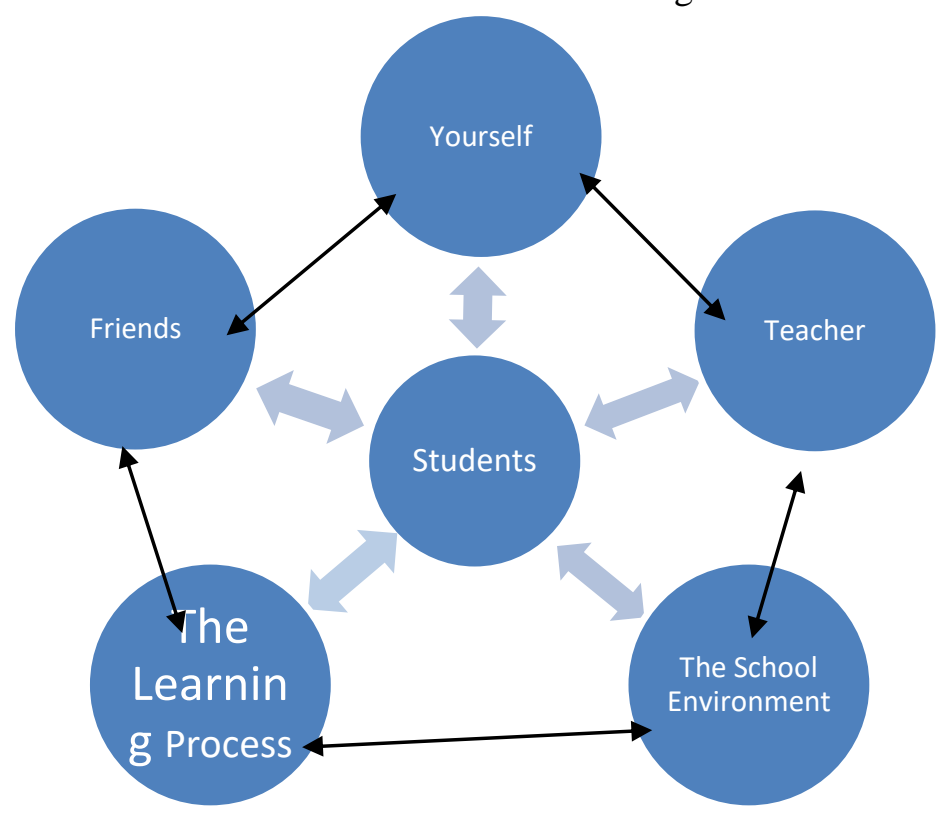


Description:

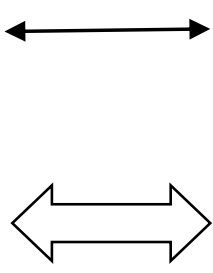

The relationship of reciprocal and mutual relationship between yourself with your friends, teachers, the school environment and the learning process.

A reciprocal relationship or interaction that very terintegratif between students and friends, between students and teachers, between students and the school, between the students with the learning process and the psychological relationship of shiva with himself.

After the Letter of the Ministry of Education and Culture dated March 17, 2020, then began the study of the house in Indonesia. As has been described above that the student is experiencing drastic changes and psychologically allows students to experience the symptoms of alienation. The term alienation is used by Karl Marx to see the life of the proletariat experience alienation. According to Marx alienation is a result of the loss of individual control over the activities of the creative itself and the production that it produces and finally alienated from his life. Means that the proletariat cannot use the products that they produce it to meet the needs of their own, although their products it actually is the embodiment of their own labor. There are four of alienation experienced by the proletariat, namely the first, alienation to work, they work continuously without having the time to interact with coworkers, without laughter and jokes so that they work but do not feel that the work was a part of his life. Second, the alienation of the results of work means they are working hard with the exertion but the salary is so small that the results of the work of the proletariat is not their guest, and the results of their work was enjoyed by bourjuis. Third, the alienation to the social environment of family and neighborhood. Time for family is hardly there anymore and spend time to work. The proletariat have a family but it looks like not live or not be in the family, it can be said the morning parents go to work, children/family members still have not wake up and by the time parents get home from work the children/family members already asleep. Likewise with the neighborhood, the house or his family was in the neighborhood, but whenever there is activity on the environment they are not present or do not participate because they went to the place of work. Thus they do not feel that they live in the environment and the environment where they are as it were only to use a bed. Fourth, the alienation of yourself as individuals should be trying to adjust to the world or circumstances that limit his freedom, even if they are not aware of it.

From that put forward by Karl Marx before, then it can be used to see the state of the First high School students in the city of teluk-dalam road that is already four months they did not meet with classmates or the school. During this time no one scolds sapa, laughter among them. Based on the findings of the research through interviews and observation it turns out that this state has made the students feel alienation. Students have school friends but not to meet with a friend so felt that not having friends of the school. They missed a meeting with friends as usual but this can not be accomplished. Furthermore, the students are alienated by his teacher, the same is the case with a friend earlier, students have the teacher but did not meet with his teacher. Students experience that there is a teacher but the teacher is only there in her mind, there were even students who felt sad because it does not meet with the teacher and friends-temnanya. Students are only able to imagined the habits of the teacher in the school or in the classroom, before the enforced learning of the house. Students feel a loss of parental figures that had been owned by his teacher who always guide and pay attention in school. Findings the results of subsequent research is that students are alienated the learning process because the learning process takes place in the room/in the building, in the field, in the laboratory and dealing directly with the teacher, discussion groups, Question and answer, now has turned the process of learning with dealing with mobile phone, laptop or television, then thus the students felt not being in a state of learning. Findings results further research is the student experience of alienation of the school environment. Students miss the atmosphere of the school environment including the whole school facilities which they enjoy for this. Usually students sit together in the cafeteria, in the cottage, in the library, or all the corners of the room or school building, group work, extracurricular activities, the classroom atmosphere in the process of learning, the sound of the bell goes, the bell exchange of les, the bell home, the ceremony of raising the flag, the line of march, now it is no longer so.

The last is based on the findings of the research that the students feel alienation towards himself. Students attend school or are registered as a student in one school but they didn't go to school. Actually students 
alienated on her own because they think that they are in school but not to school or not in school, even the students ask themselves actually I this was a school or not. All the process during this time they are natural, they run, they do, they feel, they think, after learning of the house changed instantly. The habit of getting up in the morning, saying goodbye to parents, wait for pickup, wearing a uniform school and all the habits that are conducted in schools, has now changed everything. From the findings of this study it is clear that the middle and high school students in the city of teluk-dalam road experience symptoms of alienation against your friends, the symptoms of alienation against the teacher, the symptoms of alienation on the learning process, the symptoms of alienation to the school environment and the symptoms of alienation against yourself. Students feel that they are not currently in school because all the activities they participate in during this school changed completely. Students should be trying to adjust to the world or circumstances that limit his freedom.

Picture: the State of the students learn from home

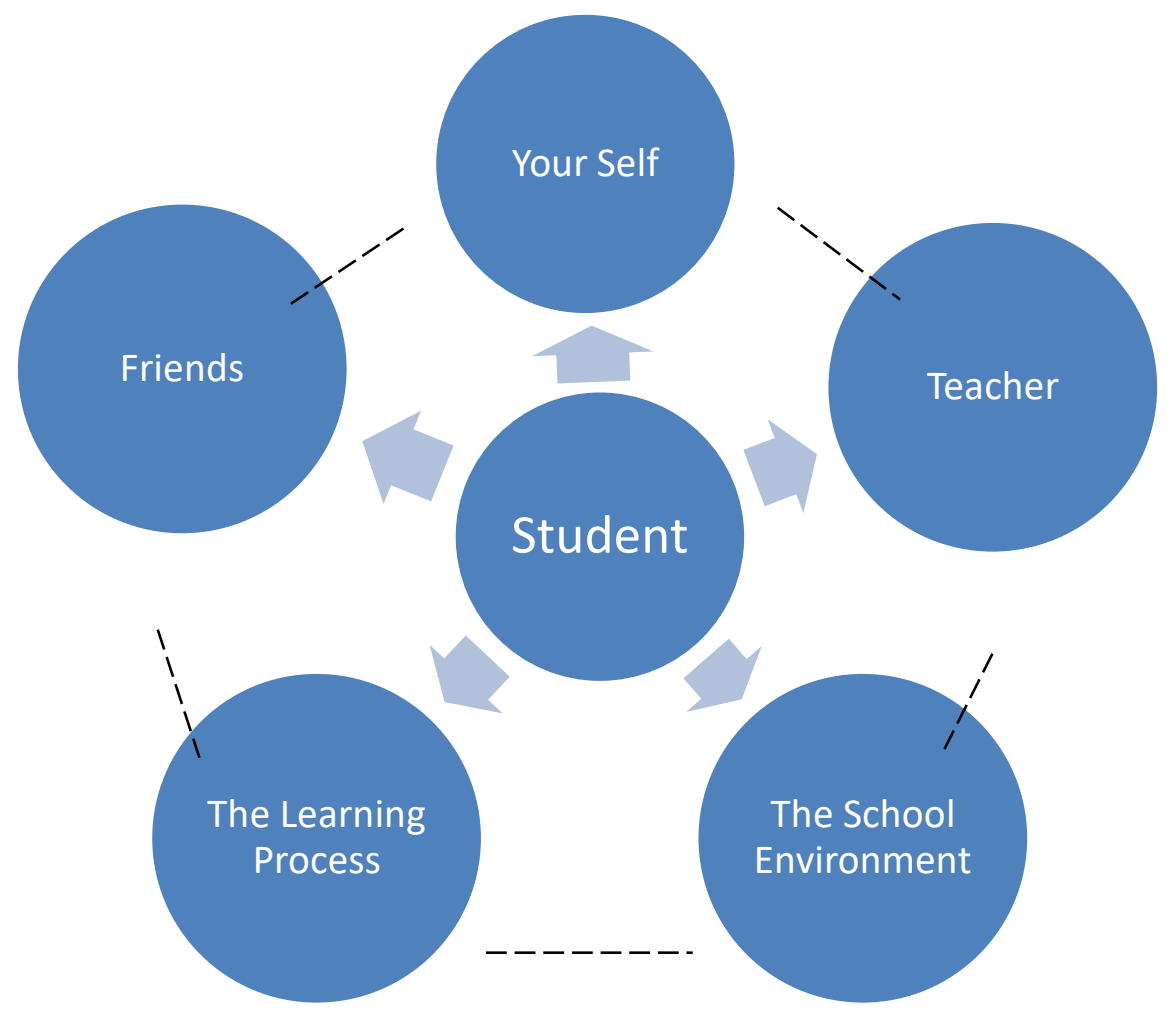

Description: ----------- Show that the relationship between yourself with your school, with teachers, the school environment, with the learning process very tenuous and does not describe the reciprocal relationship

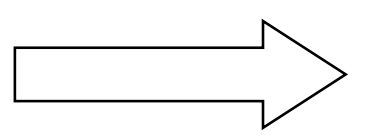

Shows that students ' relationship with your school, with teachers, with the school environment, with the learning process, even with her own looks tenuous, distant and alienated.

\section{CONCLUSION}

The results of this study is that the students first high school in Bay city in experiencing the symptoms of alienation against a friend, the symptoms of alienation against the teacher, the symptoms of alienation on the learning process, the symptoms of alienation to the school environment and the symptoms of alienation against yourself. All this happened at the time of the enactment of learning from home online through multiple applications in order to prevent an outbreak of corona virus in Indonesia. As a suggestion, so that the academics continue similar research, because the author has confidence the symptoms of alienation is likely also experiencedby the students in these areas in Indonesia and in other countries. Next may the outbreak of corona virus is quickly passed so that students can learn back at school as usual.

\section{REFERENSI}

[1]J.D. Paul, Teori Sosiologi Klasikdan Modern I.transletted by:Robert M.Z. Lawang. Jakarta: PT. Gramedia, 1986.

[2]L. Laeyendecker, Tata, Perubahan, dan Ketimpangan, Suatu Pengantar Sejarah Sosiologi. Jakarta: Gramedia,1983. 
[3]M. Rush, P.Althoff, 2003. Pengantar Sosiologi Politik. Jakarta: PT Raja Grafindo Persada. [4]Sugiyono, Metode Penelitian Kuantitatif, Kualitatif dan R\&D. Bandung: Alfabeta, 2016.

[5]V.Sujarweni,Wiratna, MetodePenelitian, Yogyakarta,Pustakabarupress, 2014.

[6]S.Kamanto, PengantarSosiologi, Jakarta,LembagaPenerbitFakultasEkonomiUniversitas Indonesia, 2004.

[7]S.Soerjono, SosiologiSuatuPengantar. Jakarta: PT Raja Grafindo Persada Cetakan ke Tiga puluh tujuh, 2004.

[8] https://www.kompasiana.com/ismidamaya/55000e118133116619fa7126/buruh-dan-lingkungan-dari-teorialienasi-marx

[9] https://www.kemdikbud.go.id/main/blog/2020/03/se-mendikbud-pembelajaran-secara-daring-dan-bekerja-darirumah-untuk-mencegah-penyebaran-covid19

[10] https://www.suara.com/lifestyle/2020/05/06/170452/mendikbud-nadiem-makarim-akui-belajar-onlinememang-menyulitkan 